\title{
MOODY'S CREDIT RATINGS AND THE STOCK MARKET PERFORMANCE OF PORTUGUESE RATED FIRMS
}

\author{
Luís Pacheco \\ Centro de Investigação em Gestão e Economia (CIGE) \\ Universidade Portucalense, Porto, Portugal \\ luisp@upt.pt
}

\begin{abstract}
:
Never has the issue of sovereign credit ratings attracted such an interest by policy and opinion makers, bankers and journalists, or even the public opinion, as witnessed in the last couple of years. In spite of being accused of contributing to the instability of financial markets, credit rating agencies undoubtedly have a role in financial markets, affecting its performance and guiding investors' decisions. This paper analyzes the impact of the changes announced in Moody's ratings over the performance of a set of rated firms quoted in the Portuguese stock market. Following an event study methodology, we collect ratings and outlook announcements by that major credit agency over the period 2006-2011. We find a significant response of share prices to changes in ratings, with that response anticipating the announcement. We think that could be explained by previous sovereign rating changes or to the contagion effects of a bearish market. When analyzing the period after January 2010, we observe a stronger reaction to announcements, which has understandably given the greater influence and market sensitivity to rating agencies.
\end{abstract}

Keywords: credit rating agencies, event studies, stock market, moody's, sovereign debt crisis, Portugal.

JEL Classification: E44; G10; G14; G24

"There are two superpowers in the world today in my opinion. There's the United States, and there's Moody's Bond Rating Service.

The United States can destroy you by dropping bombs, and Moody's can destroy you by downgrading your bonds".

Thomas Friedman (remarks at "News Hour", $13^{\text {th }}$ February, 1996)

\section{Introduction}

Never has the issue of sovereign credit ratings attracted such an interest by policy and opinion makers, bankers and journalists, or even the public opinion, as witnessed in the last couple of years ${ }^{26}$. Portugal is a case in point, with recent downgrades by the major credit agencies prompting the call for a financial rescue plan by the troika (IMF/ECB/EC).

The credit rating literature has mainly focused on analyzing the effects of bond rating changes on individual stock returns, with less literature existing on whether changes in sovereign or individual ratings have any impact on stock markets. To contribute to this research, this paper analyzes the impact of the changes

${ }^{26} \mathrm{~A}$ credit rating represents an assessment of the overall creditworthiness of an obligor in terms of both its capacity and willingness to meet its financial commitments as they fall due. Accordingly, rating agencies provide an evaluation of a country's creditworthiness and impart a rating to that country. In the case of Moody's the grade goes from Aaa to C. Rating agencies also provide an "outlook" or "watch list" with prospective changes in ratings. The outlook is typically positive, stable or negative, where a positive (negative) outlook means that a rating may be revised upward (downward). 
announced in Moody's ratings over the performance of a set of rated firms quoted in the Portuguese' stock market ${ }^{27}$. Following an event study methodology, we collected ratings and outlook announcements by that major credit agency over the period 2006-2011.

The remainder of the paper is organized as follows: section 2 reviews the main literature, section 3 describes the data and the methodology and section 4 presents the results. Closing the paper, section 5 presents a short summary of our work.

\section{Review of the Literature}

In the last twenty five years several papers have examined the response of stock returns to bond rating changes. This literature is primarily focused on the information content of bond rating change announcements. If rating agencies base their rating changes on publicly available information, the efficient market hypothesis $(E M H)$ predicts that stock prices will not adjust in response to the ratings change event. Therefore to the extent that stock prices are found to react to bond rating changes, this implies either evidence against the semi-strong form $\mathrm{EMH}$, or the presence of some private information available only to rating agencies that have, as a consequence, come into the public domain. That is rating changes may unveil (new) private information, thus fuelling rallies or downturns. Some of the main papers in this field are: Glascock et al. (1987), Hand et al. (1992), Goh, and Ederington (1993), Barron et al. (1997), Dichev, and Piotroski (2001), Joo, and Pruitt (2006) and Afonso et al. (2011). According to Subasi (2008), the main findings of these studies are three fold: first, if credit ratings are associated with significant market returns, this result supports the idea that rating agencies reveal new information to financial markets; second, in general, downgrade announcements are associated with significant negative returns in both stock and bond markets; finally, upgrade announcements rarely have an impact on stock and bond markets.

Nevertheless, the line of research that we are interested in is the effect of changes in sovereign ratings over stock markets and individual shares. Kaminsky, and Schmukler (2002) analyzed the impact of changes in sovereign rating and outlook on financial markets in emerging markets, founding that downgrades were associated with two percent increase in average bond yield spreads and about one percent decrease in average stock returns. Further, those authors found contagion effects between emerging markets and that rating changes lagged market movements. Previously, Richards, and Deddouche (1999), using emerging market bank-level data, examined the impact of bank ratings on bank stock prices. Also, Brooks et al. (2004), using a sample of developed and emerging markets over thirty years examined the impact of sovereign rating changes on stock markets. Their results indicated that rating downgrades for foreign currency were associated with significant negative excess returns, while for rating upgrades no positive excess returns were detected. More recently, Arezki et al. (2011) show that sovereign rating announcements have statistically and economically significant spillover effects both across countries and financial markets, implying that rating agencies announcements could spur financial instability. Also, the sign and the magnitude of the spillover effects depend both on the type of announcements, the source country experiencing the downgrade and the rating agency from which the announcement originates. Those authors also show that rating agencies have not anticipated the macroeconomic weaknesses of European economies consecutive to the financial crisis ${ }^{28}$.

But should sovereign rating have a clear impact on stock markets? Several authors consider that stock market participants, being rational and well informed, don't consider sovereign rating as new information, since those rating changes are anticipated by the market and hence incorporated in prices well before the change occurs [see Goh, and Ederington (1993) and Reisen, and Maltzan (1999)]. Nevertheless, if negative rating announcements take markets mostly by surprise, that could either imply that fundamentals are not fully

${ }^{27}$ Moody's began rating the creditworthiness of countries in 1974. The first rating for Portugal was assigned in 1995 and for a Portuguese firm in 2006.

28 This delay by rating agencies is also evidenced in papers by Mora (2006) and White (2010). 
discounted by market participants or that, at least on some occasions, rating events diverged from such fundamentals. Finally, Reinhart (2001) examines whether rating agencies actions anticipated the crisis of the 1990 's. With a large sample of countries and crises, the author concludes that rating changes far from being leading indicators of crises have turned out to be lagging indicators of financial collapses. So, the aftermath of rating changes could be something uneventful, with no changes after the announcement and with variables maintaining the gains or losses observed in the preceding days.

\section{Data and Research Methodology}

To analyze the impact of credit ratings on the Portuguese stock market, we collect individual ratings emanated from Moody's credit rating agency since 200629. The rating announcements are obtained from its web page. For the selected firms, our observation period for which we have both rating and outlook changes includes 49 events, out of which 17 are downgrades. The others are outlooks, predominantly negative and in the period analyzed there were no upgrades ${ }^{30}$. Table 1 reports the different credit rating events for Portugal and Table 2 presents the rating events for the seven selected firms.

Table 1. Moody's sovereign rating announcements and actions

\begin{tabular}{|c|c|c|c|c|}
\hline Date & \multicolumn{2}{c|}{ Rating } & \multicolumn{2}{c|}{ Outlook } \\
\hline & upgrades & downgrades & upgrades & Downgrades \\
\hline $05-07-2011$ & & from Baa1 to Ba2 & & Negative \\
\hline $05-04-2011$ & & from A3 to Baa1 & & on review \\
\hline $15-03-2011$ & & from A1 to A3 & & Negative \\
\hline $21-12-2010$ & & & & possible downgrade \\
\hline $13-07-2010$ & & from Aa2 to A1 & & Stable \\
\hline $05-05-2010$ & & & & possible downgrade \\
\hline $29-10-2009$ & & & & negative \\
\hline
\end{tabular}

Source: Moody's.

Comparing both Tables, we clearly see that Moody's tends to downgrade the PSI-20 firms the day after Portugal's downgrade. Also, the data shows that changes in outlook are followed by changes in rating. As we can see, roughly 67 percent of the changes in outlook are followed by a change in the rating, the time interval between changes being around two months.

Table 2. Moody's rating announcements and actions for the selected quoted firms

\begin{tabular}{|c|c|c|}
\hline BRISA & \multicolumn{2}{|c|}{} \\
\hline Date & Rating & Rating Action \\
\hline
\end{tabular}

\begin{tabular}{|c|c|c|}
\hline PT & \multicolumn{2}{|c}{} \\
\hline Date & Rating & Rating Action \\
\hline
\end{tabular}

${ }^{29}$ Deciding to choose only one rating agency, we opted for Moody's due to its historical presence and influence [confirmed, for instance, by Arezki et al. (2011)].

${ }^{30}$ We consider changes in outlook provided they tend to anticipate movements in the rating notation, so that the information content of the outlook is in itself valuable for explaining the movements of share prices. 
Volume III Issue 1 (5) Summer 2012

\begin{tabular}{|c|c|c|}
\hline 08-07-2011 & Baa3 & Downgrade \\
\hline 06-04-2011 & Baa1 & $\begin{array}{c}\text { Possible } \\
\text { downgrade }\end{array}$ \\
\hline $22-12-2010$ & Baa1 & Unchanged \\
\hline $24-12-2008$ & Baa1 & $\begin{array}{c}\text { Possible } \\
\text { downgrade }\end{array}$ \\
\hline 04-08-2008 & Baa1 & Downgrade \\
\hline $29-11-2006$ & A3 & New \\
\hline
\end{tabular}

\begin{tabular}{|c|c|c|} 
29-07-2011 & Baa3 & $\begin{array}{c}\text { Confirm negative } \\
\text { outlook }\end{array}$ \\
\hline $08-07-2011$ & Baa3 & $\begin{array}{c}\text { Possible } \\
\text { downgrade }\end{array}$ \\
\hline $07-06-2011$ & Baa3 & Downgrade \\
\hline $06-04-2011$ & Baa2 & $\begin{array}{c}\text { Possible } \\
\text { Downgrade }\end{array}$ \\
\hline $05-03-2007$ & Baa2 & $\begin{array}{c}\text { Confirm only } \\
\text { (P.R.) }\end{array}$ \\
\hline
\end{tabular}

\begin{tabular}{|c|c|c|}
\hline BPI & & \\
\hline Date & Rating & Rating Action \\
\hline $15-07-2011$ & Baa3 & Downgrade \\
\hline 06-04-2011 & Baa2 & $\begin{array}{c}\text { Possible } \\
\text { downgrade }\end{array}$ \\
\hline $09-12-2010$ & A2 & $\begin{array}{c}\text { Possible } \\
\text { downgrade }\end{array}$ \\
\hline $14-07-2010$ & A2 & Downgrade \\
\hline $05-05-2010$ & A1 & $\begin{array}{c}\text { Possible } \\
\text { downgrade }\end{array}$ \\
\hline $16-09-2009$ & A1 & Confirm only (P.R.) \\
\hline 06-04-2009 & $\mathrm{A} 1$ & $\begin{array}{c}\text { Possible } \\
\text { downgrade }\end{array}$ \\
\hline 13-04-2007 & A1 & New \\
\hline
\end{tabular}

\begin{tabular}{|c|c|c|}
\hline BES & \multicolumn{2}{|c|}{} \\
\cline { 1 - 1 } Date & Rating & Rating Action \\
\hline 15-07-2011 & Ba1 & Downgrade \\
\hline $06-04-2011$ & Baa2 & $\begin{array}{c}\text { Possible } \\
\text { downgrade }\end{array}$ \\
\hline $09-12-2010$ & A2 & $\begin{array}{c}\text { Possible } \\
\text { downgrade }\end{array}$ \\
\hline $14-07-2010$ & A2 & Downgrade \\
\hline $05-05-2010$ & A1 & $\begin{array}{c}\text { Possible } \\
\text { downgrade }\end{array}$ \\
\hline $16-09-2009$ & A1 & $\begin{array}{c}\text { Downgrade } \\
\text { Possible } \\
\text { downgrade }\end{array}$ \\
\hline $06-04-2009$ & Aa3 & New \\
\hline $13-04-2007$ & Aa3 & \\
\hline
\end{tabular}

\begin{tabular}{|c|c|c|}
\hline $\mathrm{BCP}$ & & \\
\hline Date & Rating & Rating Action \\
\hline $15-07-2011$ & Ba1 & Downgrade \\
\hline 06-04-2011 & Baa3 & $\begin{array}{c}\text { Possible } \\
\text { downgrade }\end{array}$ \\
\hline 09-12-2010 & A3 & $\begin{array}{c}\text { Possible } \\
\text { downgrade }\end{array}$ \\
\hline $14-07-2010$ & A3 & Downgrade \\
\hline 05-05-2010 & A1 & $\begin{array}{c}\text { Possible } \\
\text { downgrade }\end{array}$ \\
\hline $16-09-2009$ & A1 & Downgrade \\
\hline 06-04-2009 & Aa3 & $\begin{array}{c}\text { Possible } \\
\text { downgrade }\end{array}$ \\
\hline 13-04-2007 & Aa3 & New \\
\hline
\end{tabular}

\begin{tabular}{|c|c|c|}
\hline EDP & \multicolumn{2}{|c|}{} \\
\hline Date & Rating & Rating Action \\
\hline $06-07-2011$ & Baa3 & Downgrade \\
\hline $17-03-2011$ & Baa1 & $\begin{array}{c}\text { Possible } \\
\text { downgrade }\end{array}$ \\
\hline $21-12-2010$ & Baa1 & Downgrade \\
\hline $09-06-2009$ & A3 & $\begin{array}{c}\text { Possible } \\
\text { downgrade }\end{array}$ \\
\hline $19-10-2007$ & A2 & $\begin{array}{c}\text { Confirm only } \\
\text { (P.R.) }\end{array}$ \\
\hline $27-03-2007$ & A2 & $\begin{array}{c}\text { Possible } \\
\text { downgrade }\end{array}$ \\
\hline
\end{tabular}




\begin{tabular}{|c|c|c|}
\hline REN & & \\
\hline Date & Rating & Rating Action \\
\hline 08-07-2011 & Baa3 & Downgrade \\
\hline 06-04-2011 & Baa2 & $\begin{array}{l}\text { Possible } \\
\text { downgrade }\end{array}$ \\
\hline 17-03-2011 & Baa1 & Downgrade \\
\hline $21-12-2010$ & A3 & $\begin{array}{c}\text { Possible } \\
\text { downgrade }\end{array}$ \\
\hline $13-07-2010$ & A3 & Downgrade \\
\hline 05-05-2010 & $\mathrm{A} 2$ & $\begin{array}{l}\text { Possible } \\
\text { downgrade }\end{array}$ \\
\hline 28-04-2008 & $\mathrm{A} 2$ & New \\
\hline
\end{tabular}

Source: Moody's.

Regarding the stock market data, we obtained daily quotes for seven individual shares and for the PSI-20 market index from the site bolsapt.com. We analyzed the period from September 2006 to the end of July $2011^{31}$. The performance of the PSI-20 index in the considered period is illustrated by the following graph:

PSI-20

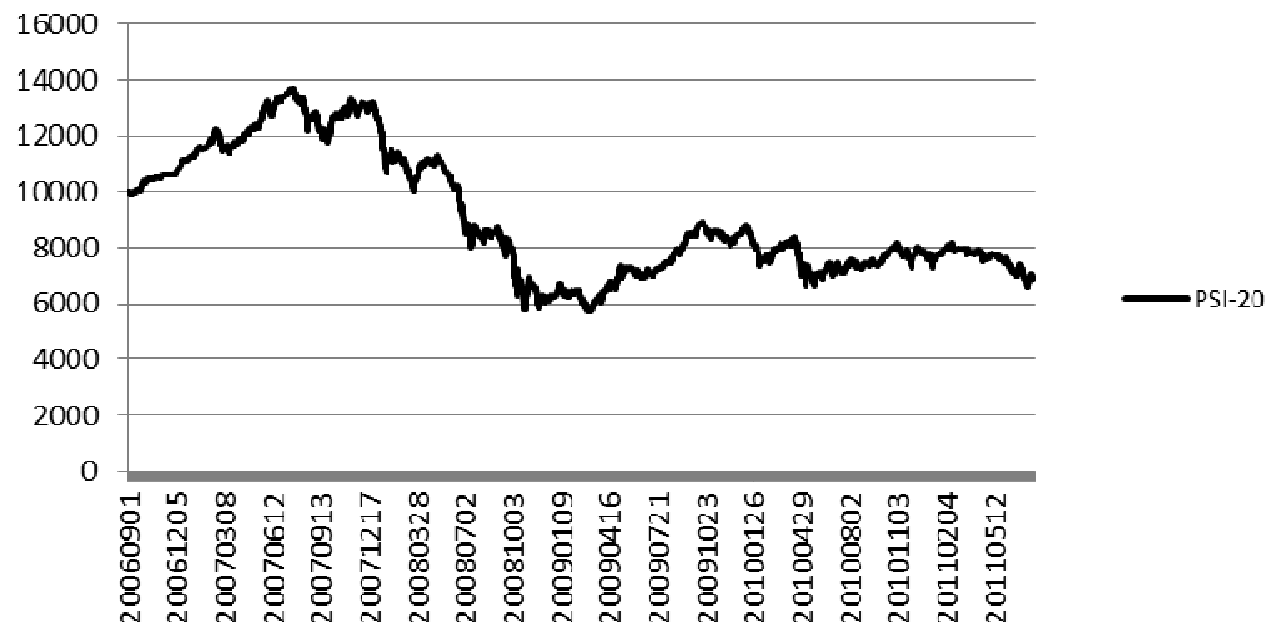

Figure 1. PSI-20 index

Source: www.bolsapt.com

The performance of these seven shares in the considered period is illustrated by the following graph:

311263 days, except for REN that starts in July 2007. We choose this period because only after 2006/2007 did some Portuguese quoted firms started being rated by Moody's. This period also encompasses the start of the sub-prime crisis, the ensuing financial and economic crisis and the recent sovereign debt crisis felt in Europe. 


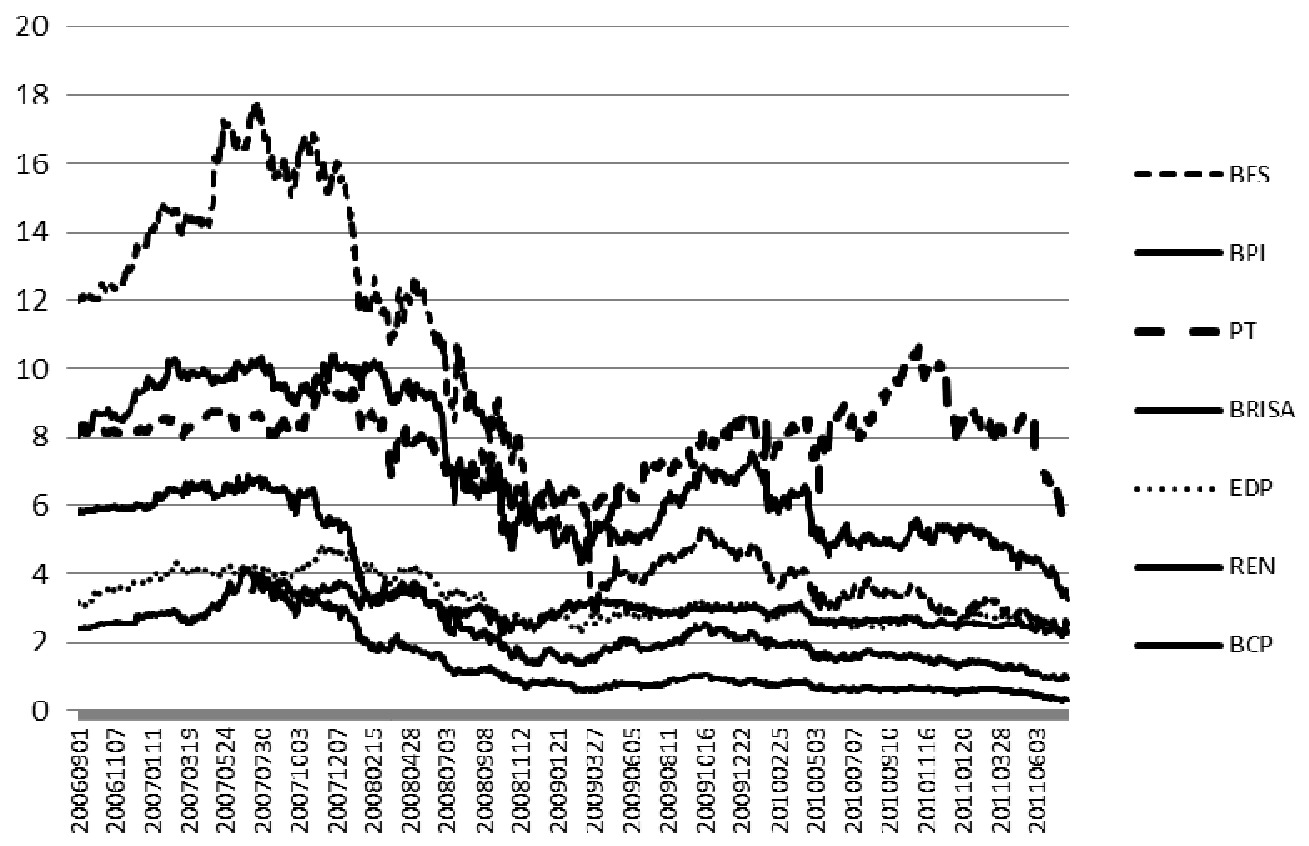

Figure 2. Selected shares (values in $€$ )

\section{Source: www.bolsapt.com}

The methodological starting point of this paper is to recognize that standard time-series techniques may not be well suited when dealing with the analysis of rating announcements and stock market performance. Stock market quotes are typically highly volatile on a day-to-day basis and rating announcements are infrequent, occurring on a single day. So, to overcome these problems, most papers have used so far event study techniques, where each individual credit rating and outlook changes are defined as a single event ${ }^{32}$. Afterwards, an event period is defined, comprising the six prior event days, the event day and the four post-event days, over which stock returns will be examined. The use of this narrow window allows reducing contamination problems which may bias the results of the analysis.

The event study methodology allows us to study the effect of a downgrade on the evolution of stock prices around the event. Of course, other factors might take place at the same time, which also affect the evolution of stock prices ${ }^{33}$. Standard event-study methodology requires linking rating events to abnormal returns. Traditionally, daily risk adjusted abnormal market returns (ar) are derived from the conventional market model:

$$
\operatorname{ar}_{\mathrm{it}}=\mathrm{rit}_{\mathrm{it}}-\left(\alpha_{\mathrm{i}}+\beta_{\mathrm{i}} \mathrm{r}_{\mathrm{mt}}\right)
$$

where $r_{i t}$ is the return on asset $i$ at day $t$

$r_{m t}$ is the corresponding return on the PSI-20 index at day $t$, and $\alpha_{i}$ and $\beta_{i}$ are the market model parameters obtained from an OLS regression applied to all the period.

Afterwards, we compute the average abnormal return (aar) in each window day:

${ }^{32}$ An important reference for such an approach applied to sovereign ratings is Gande, and Parsley (2005). For one of the first applications of event study methodology to financial markets, see Brown, and Warner (1980).

${ }_{33}$ We are not controlling for those factors and we assume that on average there is no particular bias in the event studies. We expect that those other factors influence stock prices both positively and negatively in a random way. 


$$
\operatorname{aar}_{t}=\frac{1}{N} \sum_{i=1}^{N} \operatorname{ar}_{i 1}
$$

where $\mathrm{N}$ is the number of events. The average abnormal return is also aggregated through the event window, originating the cumulative average abnormal returns (caar). For any interval $\left(t_{1}=-6, t_{2}=4\right)$ in the event window, caar is defined as:

$$
\operatorname{caar}\left(\mathrm{t}_{1}, \mathrm{t}_{2}\right)=\sum_{\mathrm{t}_{\mathrm{t}} \mathrm{t}_{1}}^{\mathrm{t}_{2}} \operatorname{car}_{\mathrm{t}}
$$

The null hypothesis $(\mathrm{H} 0)$ that the event has no impact in share prices before the announcement could be tested by the following statistics:

$$
\begin{aligned}
& \theta_{1}=\frac{\operatorname{aar}_{1}}{\operatorname{var}_{1}\left(a_{1}\right)^{1 / 2}} \sim N(0,1) \\
& \theta_{2}=\frac{\operatorname{caar}(-6,4)}{\operatorname{varcaar}(-6,4)^{1 / 2}} \sim N(0,1)
\end{aligned}
$$

The results for these statistics are in the Appendix (Tables A4 and A5).

a. Empirical Results

Performing an OLS regression, we obtain the following estimated $\beta$ and $R^{2}$ for each share:

Table 3. Estimated $\beta$ and $\mathrm{R}^{2}$

\begin{tabular}{|c|c|c|}
\hline Shares & $\boldsymbol{\beta}$ & $\mathbf{R}^{\mathbf{2}}$ \\
\hline BES & $\begin{array}{c}0,282 \\
(5,71)^{* * *}\end{array}$ & 0,025 \\
\hline BPI & $\begin{array}{c}1,034 \\
(28,72)^{* * *}\end{array}$ & 0,396 \\
\hline BCP & $\begin{array}{c}1,244 \\
(35,222)^{* * *}\end{array}$ & 0,496 \\
\hline PT & $\begin{array}{c}0,934 \\
(30,103)^{* * *}\end{array}$ & 0,418 \\
\hline BRISA & $\begin{array}{c}0,404 \\
(11,525)^{* * *}\end{array}$ & 0,095 \\
\hline EDP & $\begin{array}{c}0,969 \\
(40,724)^{* * *}\end{array}$ & 0,568 \\
\hline REN & $\begin{array}{c}0,522 \\
(17,156)^{* * *}\end{array}$ & 0,221 \\
\hline
\end{tabular}

Note: the values in brackets represent the t-statistics and ${ }^{* * *}$ denotes a $1 \%$ significance level. 
A simple normality test shows that the abnormal returns do not present a normal distribution with zero mean and constant variance (see Table $\mathrm{A} 1$ in the Appendix) ${ }^{34}$.

Concerning the individual abnormal returns (Tables A2 and A3 in the Appendix) we concluded that with the exception of Brisa and PT, the caar are negative since the beginning of the event window, decreasing rapidly in the following days, with the exception of Brisa and EDP. At the end of the event window, only BPI is positive, with EDP barely untouched. This suggests the possibility of market anticipation of the announcement. There is also a different performance of the caar after day 0 . For instance, PT continues to decrease, whereas BES and BCP seem to stabilize around session 3. Since it is risky to take conclusions from individual shares, the following Figures present the average abnormal returns and the cumulative average abnormal returns before and after an announcement, but now in aggregate terms. For presentation purposes we distinguished between banks (BES, $\mathrm{BPI}$ and $\mathrm{BCP}$ ) and ex-banks (PT, BRISA, EDP and REN). Table A2 in the Appendix presents the values of those two variables for these different groups: total, banks and ex-banks.

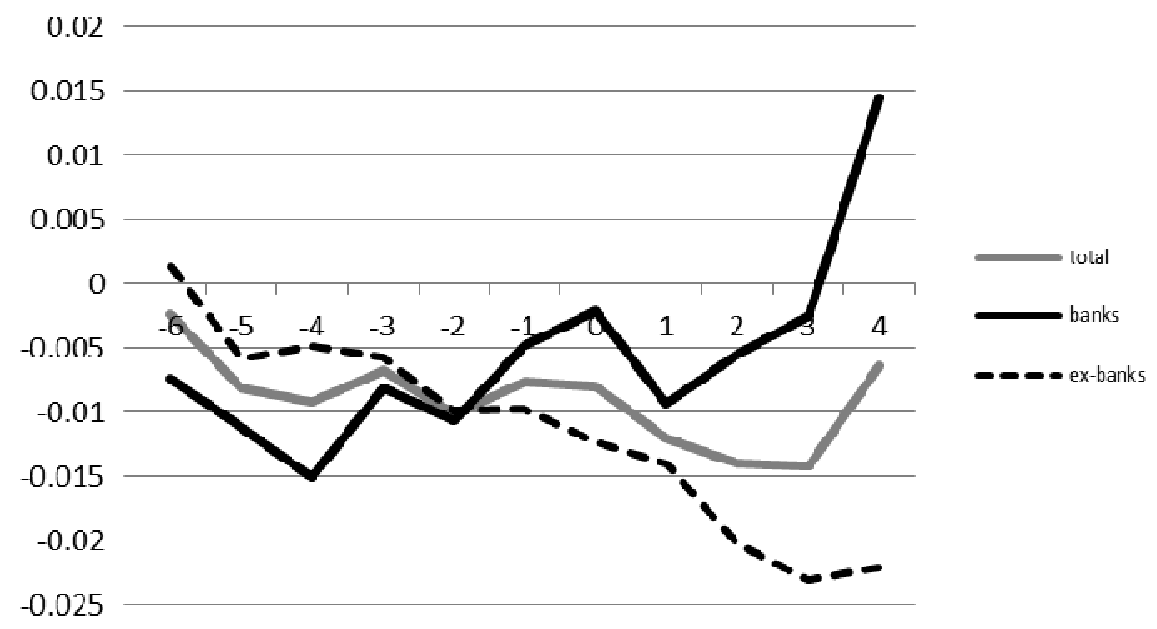

Figure 3. Average abnormal returns before and after an announcement

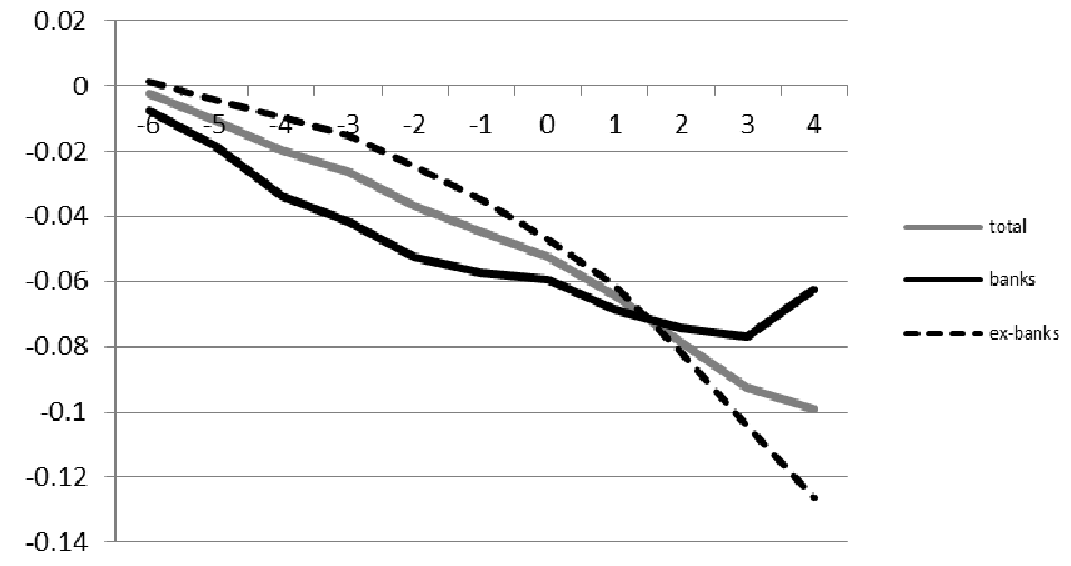

Figure 4. Cumulative average abnormal returns before and after an announcement

${ }^{34}$ Even that the distributions aren't normal, the central limit theorem assures that if the values for the abnormal returns for all the shares are i.i.d. then the average distribution of the sample's abnormal returns converges to normality as the number of shares in the sample increases. 
The Figures present some evidence of an anticipation of the downgrade by the market players, yet with some reversal after day 0 . This reversal is stronger in the banking sector, while ex-banks continue to display negative abnormal returns. Notice that, since usually the firm downgrade occurs days after the sovereign downgrade, it is natural to observe some anticipation, whereas the bearish sentiment felt in the market also contributes.

Nevertheless, when we consider only a more recent period beginning in January 2010, as marking the inception of the sovereign debt crisis, the average abnormal returns and the cumulative average abnormal returns present a somehow different pattern (Figures 5 and 6 ). Table $A 3$ also presents these results.

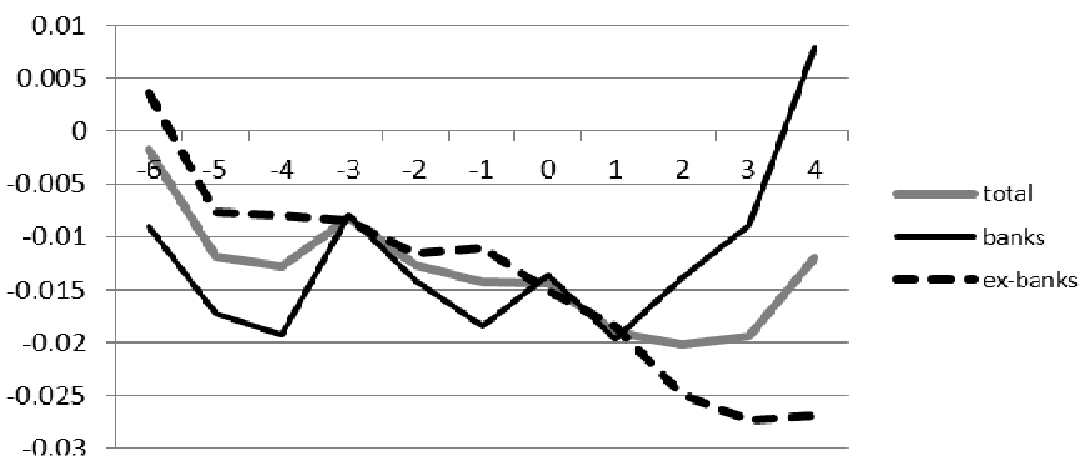

Figure 5. Average abnormal returns before and after an announcement (after January 2010)

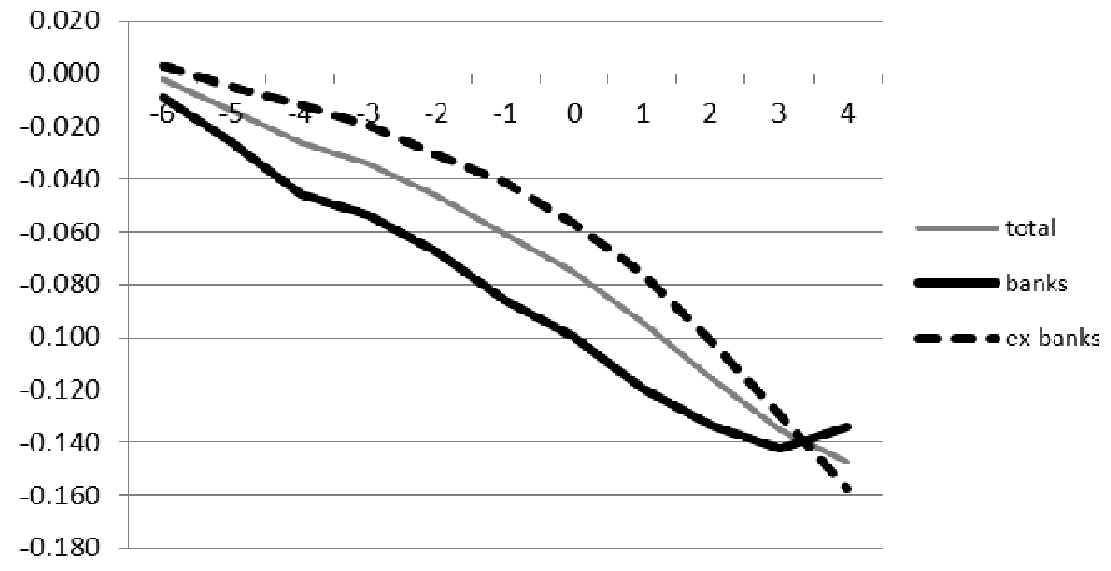

Figure 6. Cumulative average abnormal returns before and after an announcement (after January 2010)

Now all the shares, and in particular the banking ones, display a stronger negative reaction to downgrades, anticipating those events. At the announcement date we observe a total aar of $-1.5 \%$ and the numbers continue to decrease in the following days. Also, now it is clearly the banking sector that pushes down the abnormal returns, before and after an announcement, albeit the first that starts to recover.

In terms of significance, Tables A4 and A5 in the Appendix show the results for statistics $\theta_{1}$ and $\theta_{2}$. The average abnormal returns are more significant after the announcement date, although they aren't significant for the banking sector. Considering only the period after January 2010, the significance tests are slightly more robust, nevertheless continuing weak for banks. Notice that, in both cases we continue to observe highly significant average abnormal returns after the announcement date. In relation to the cumulative average 
abnormal returns, they only become significant after the announcement date (with the exception of the banking sector). Also in the period after January 2010, the results for the cumulative average abnormal returns become more significant in the post-announcement phase, suggesting the presence of a drift or contagion in share prices.

Finally, we analyze causality between sovereign credit ratings and share prices. In order to perform a causality test between announcements and stock returns we transform the ratings into a discrete variable, ranging from 1 to 17 (Table $A 6$ in the Appendix) ${ }^{35}$. We do not find causality between ratings and returns and we could not reject the null in all cases, except for PT, where we reject the null that the stock returns do not cause the rating (Table A7 in the Appendix).

\section{Conclusion}

This paper analyzed the impact of the changes announced in credit ratings over the performance of a set of rated firms quoted in the Portuguese stock market. We found a significant response of share prices to changes in both the credit rating notations and in the outlook. This response seems to anticipate the announcements, either due to a previous sovereign downgrade or to the contagion effects of a bearish market outlook. Also, when analyzing the period after January 2010, we observed a stronger negative reaction to announcements, which is understandable given the greater influence and market sensitivity to rating agencies. These conclusions shed some light on the connection between share prices' performance and individual credit ratings. The fact that negative rating events don't take share prices by surprise can either imply that fundamentals are already fully discounted by market participants or that rating events go, with some delay, after such fundamentals. This is a simple exercise, which could benefit from several extensions: first, it would be interesting to study whether the three main rating agencies affect stock prices differently; also, an additional extension would be to use more complete models to compute abnormal returns; finally, since usually individual rating changes occur days after a sovereign rating change, we could also relate the individual firms performance in the stock market with changes in sovereign ratings.

\section{References}

[1] Afonso, A., Furceri, D., and Gomes, P. 2011. Sovereign Credit Ratings and Financial Market Linkages. Working Paper Series, no. 1347. European Central Bank.

[2] Arezki, R., Candelon, B., and Sy, A. 2011. Sovereign Rating News and Financial Market Spillovers: evidence from the European Debt Crisis. Working Paper, no. 11/68.

[3] Barron, M.J., Clare, A.D., and Thomas, S.H. 1997. The Effect of Bond Rating Changes and New Ratings on UK Stock Returns. Journal of Business Finance and Accounting, no. 24(3): 497-509.

[4] Brooks, R., Faff, R.B., Hillier, D., and Hillier, J. 2004. The National Market Impact of Sovereign Rating Changes. Journal of Banking and Finance, no. 28: 233-250.

[5] Brown, S., and Warner, J. 1980. Measuring Security Price Performance. Journal of Financial Economics, no. 8: 205-258.

\footnotetext{
${ }^{35}$ Afonso et al. (2011) perform a similar analysis.
} 
[6] Dichev, I.D., and Piotroski, J.D. 2001. The Long-run Stock Returns Following Bond Ratings Changes. Journal of Finance, no. LVI(1): 173-203.

[7] Gande, A., and Parsley, D.C. 2005. News Spillovers in the Sovereign Debt Market. Journal of Financial Economics 75(3): 691-734.

[8] Glascock, J.L.; Davidson, W.N., and Henderson, G.V. 1987. Announcement Effects of Moody's Bond Rating Changes on Equity Returns. Quarterly Journal of Business and Economics, no. 26: 6778.

[9] Goh, J.C., and Ederington, L.H. 1993. Is a Bond Rating Downgrade Bad News, Good News, or no News for Stockholders? The Journal of Finance, no. 48(5): 2001-2008.

[10] Hand, J.R., Holthausen, R.W., and Leftwich, R.W. 1992. The Effect of Bond Rating Agency Announcements on Bond and Stock Prices. Journal of Finance, no. 47: 733-752.

[11] Joo, S.L., and Pruitt, S.W. 2006. Corporate Bond Ratings Changes and Economic Instability: evidence from the Korean financial crisis. Economic Letters, no. 90(1): 12-20.

[12] Kaminsky, G., and Schmukler, S. 2002. Emerging Markets Instability: do sovereign credit ratings affect country risk and stock returns? World Bank Economic Review, no. 16: 171-195.

[13] Mora, N. 2006. Sovereign Credit Ratings: guilty beyond reasonable doubt? Journal of Banking and Finance, no. 30: 2041-2062.

[14] Reinhart, C. 2001. Do Sovereign Credit Ratings Anticipate Financial Crisis: evidence for emerging markets. Journal of Finance, no. 52: 2129-2144.

[15] Reisen, H., and Maltzan, J. 1999. Boom and Bust and Sovereign Ratings. International Finance, no. 2: 273-293.

[16] Subasi, F. 2008. The Effect of Sovereign Rating Changes on Stock Returns and Exchange Rates. International Research Journal of Finance and Economics, no. 20: 46-54.

[17] White, L. 2010. Markets: the credit rating agencies. Journal of Economic Perspectives, no. 24(2): 211-226. 


\section{APPENDIX}

Table A1. Abnormal returns - normality test

\begin{tabular}{|l|c|c|c|c|c|c|c|}
\cline { 2 - 9 } & BES & BPI & BCP & PT & BRISA & EDP & REN \\
\hline Skewness & $-3,882756$ & 0,228166 & $-0,128972$ & $-0,451994$ & $-0,854495$ & 0,079787 & $-0,364509$ \\
\hline Kurtosis & 75,50917 & 9,823372 & 4,907130 & 22,28858 & 8,971082 & 7,191521 & 12,29321 \\
\hline Jarque-Bera & 279632,0 & 2459,146 & 194,7518 & 19606,56 & 2028,374 & 925,1677 & 3769,078 \\
\hline Prob. & 0 & 0 & 0 & 0 & 0 & 0 & 0 \\
\hline$N^{0}$. of observ. & 1262 & 1262 & 1262 & 1262 & 1262 & 1262 & 1041 \\
\hline
\end{tabular}

Figure A1. Abnormal returns for the individual shares

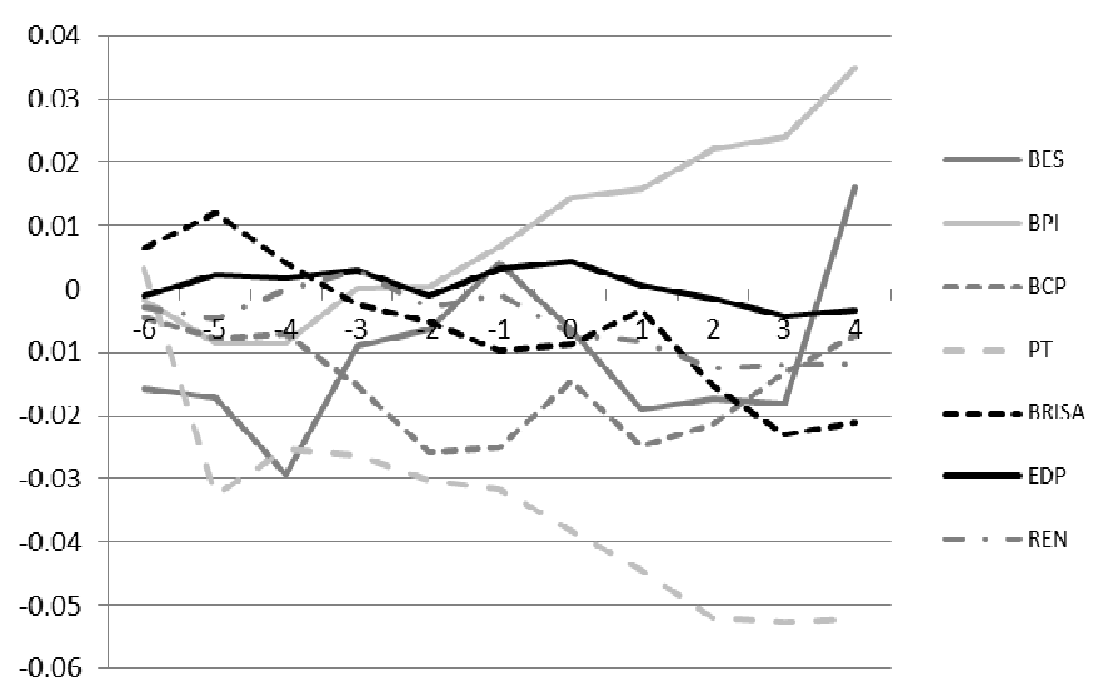

Figure A2. Cumulative average abnormal returns for the individual shares

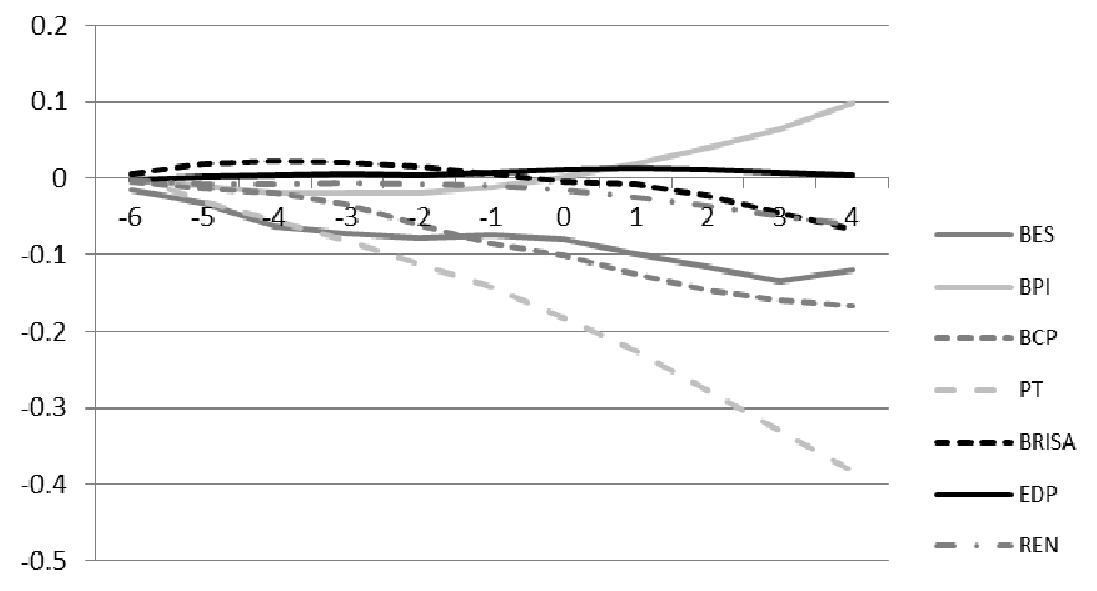


Table A2. Average abnormal returns and cumulative average abnormal returns

\begin{tabular}{|c|c|c|c|c|c|c|}
\hline \multirow{2}{*}{ Days } & \multicolumn{2}{|c|}{ Total } & \multicolumn{2}{c|}{ Banks } & \multicolumn{2}{c|}{ Ex-Banks } \\
& AAR & CAAR & AAR & CAAR & AAR & CAAR \\
\hline-6 & $-0,002$ & $-0,002$ & $-0,007$ & $-0,007$ & 0,001 & 0,001 \\
\hline-5 & $-0,008$ & $-0,011$ & $-0,011$ & $-0,019$ & $-0,006$ & $-0,004$ \\
\hline-4 & $-0,009$ & $-0,020$ & $-0,015$ & $-0,034$ & $-0,005$ & $-0,009$ \\
\hline-3 & $-0,007$ & $-0,027$ & $-0,008$ & $-0,042$ & $-0,006$ & $-0,015$ \\
\hline-2 & $-0,010$ & $-0,037$ & $-0,011$ & $-0,052$ & $-0,010$ & $-0,025$ \\
\hline-1 & $-0,008$ & $-0,044$ & $-0,005$ & $-0,057$ & $-0,010$ & $-0,035$ \\
\hline 0 & $-0,008$ & $-0,052$ & $-0,002$ & $-0,059$ & $-0,012$ & $-0,047$ \\
\hline 1 & $-0,012$ & $-0,064$ & $-0,009$ & $-0,069$ & $-0,014$ & $-0,061$ \\
\hline 2 & $-0,014$ & $-0,078$ & $-0,006$ & $-0,074$ & $-0,020$ & $-0,081$ \\
\hline 3 & $-0,014$ & $-0,093$ & $-0,002$ & $-0,077$ & $-0,023$ & $-0,104$ \\
\hline 4 & $-0,006$ & $-0,099$ & 0,014 & $-0,062$ & $-0,022$ & $-0,127$ \\
\hline
\end{tabular}

Table A3. Average abnormal returns and cumulative average abnormal returns (after January 2010)

\begin{tabular}{|c|c|c|c|c|c|c|}
\hline \multirow{2}{*}{ Days } & \multicolumn{2}{|c|}{ Total } & \multicolumn{2}{c|}{ Banks } & \multicolumn{2}{c|}{ Ex-Banks } \\
\cline { 2 - 7 } & AAR & CAAR & AAR & CAAR & AAR & CAAR \\
\hline-6 & $-0,002$ & $-0,002$ & $-0,009$ & $-0,009$ & 0,003 & 0,003 \\
\hline-5 & $-0,012$ & $-0,014$ & $-0,017$ & $-0,026$ & $-0,008$ & $-0,008$ \\
\hline-4 & $-0,012$ & $-0,026$ & $-0,019$ & $-0,046$ & $-0,007$ & $-0,007$ \\
\hline-3 & $-0,008$ & $-0,034$ & $-0,008$ & $-0,054$ & $-0,008$ & $-0,008$ \\
\hline-2 & $-0,012$ & $-0,046$ & $-0,014$ & $-0,068$ & $-0,011$ & $-0,011$ \\
\hline-1 & $-0,014$ & $-0,061$ & $-0,018$ & $-0,086$ & $-0,011$ & $-0,011$ \\
\hline 0 & $-0,015$ & $-0,075$ & $-0,014$ & $-0,100$ & $-0,016$ & $-0,016$ \\
\hline 1 & $-0,019$ & $-0,095$ & $-0,020$ & $-0,120$ & $-0,019$ & $-0,019$ \\
\hline 2 & $-0,021$ & $-0,115$ & $-0,014$ & $-0,133$ & $-0,026$ & $-0,026$ \\
\hline 3 & $-0,020$ & $-0,135$ & $-0,009$ & $-0,142$ & $-0,028$ & $-0,028$ \\
\hline 4 & $-0,012$ & $-0,148$ & 0,008 & $-0,134$ & $-0,028$ & $-0,028$ \\
\hline
\end{tabular}


Table A4. Values for $\theta_{1}$ and $\theta_{2}$ and significance levels

\begin{tabular}{|c|c|c|c|c|c|c|}
\hline \multirow{2}{*}{ Days } & \multicolumn{2}{|c}{ Total } & \multicolumn{2}{c}{ Banks } & \multicolumn{2}{c|}{ Ex-Banks } \\
\cline { 7 - 8 } & $\boldsymbol{\theta}_{1}$ & $\boldsymbol{\theta}_{2}$ & $\boldsymbol{\theta}_{1}$ & $\boldsymbol{\theta}_{2}$ & $\boldsymbol{\theta}_{1}$ & $\boldsymbol{\theta}_{2}$ \\
\hline-6 & $-0,721$ & $-0,077$ & $-1,011$ & $-0,345$ & 0,186 & 0,034 \\
\hline-5 & $-2,449$ & $-0,338$ & $-1,525$ & $-0,865$ & $-0,784$ & $-0,109$ \\
\hline-4 & $-2,784^{* *}$ & $-0,634$ & $-2,044$ & $-1,563$ & $-0,661$ & $-0,230$ \\
\hline-3 & $-2,036$ & $-0,851$ & $-1,100$ & $-1,938$ & $-0,776$ & $-0,372$ \\
\hline-2 & $-3,079^{* *}$ & $-1,179$ & $-1,453$ & $-2,434^{*}$ & $-1,330$ & $-0,615$ \\
\hline-1 & $-2,311^{*}$ & $-1,426$ & $-0,661$ & $-2,659^{*}$ & $-1,317$ & $-0,856$ \\
\hline 0 & $-2,406^{*}$ & $-1,682$ & $-0,294$ & $-2,759^{*}$ & $-1,663$ & $-1,159$ \\
\hline 1 & $-3,614^{* * *}$ & $-2,067$ & $-1,273$ & $-3,194^{* * *}$ & $-1,882$ & $-1,503$ \\
\hline 2 & $-4,203^{* * *}$ & $-2,515^{*}$ & $-0,761$ & $-3,454^{* *}$ & $-2,722^{*}$ & $-2,001$ \\
\hline 3 & $-4,284^{* * *}$ & $-2,971^{* *}$ & $-0,340$ & $-3,570^{* * *}$ & $-3,098^{* *}$ & $-2,566^{*}$ \\
\hline 4 & $-1,932$ & $-3,177^{* * *}$ & 1,968 & $-2,898^{* *}$ & $-2,970^{* *}$ & $-3,109^{* *}$ \\
\hline
\end{tabular}

Table A5. Values for $\theta_{1}$ and $\theta_{2}$ and significance levels (after January 2010)

\begin{tabular}{|c|c|c|c|c|c|c|}
\hline \multirow{2}{*}{ Days } & \multicolumn{2}{c}{ Total } & \multicolumn{2}{c|}{ Banks } & \multicolumn{2}{c|}{ Ex-Banks } \\
\cline { 7 - 8 } & $\boldsymbol{\theta}_{1}$ & $\boldsymbol{\theta}_{2}$ & $\boldsymbol{\theta}_{\mathbf{1}}$ & $\boldsymbol{\theta}_{\mathbf{2}}$ & $\boldsymbol{\theta}_{\mathbf{1}}$ & $\boldsymbol{\theta}_{\mathbf{2}}$ \\
\hline-6 & $-0,440$ & $-0,048$ & $-1,201$ & $-0,205$ & 0,298 & 0,055 \\
\hline-5 & $-2,283^{*}$ & $-0,297$ & $-2,298^{*}$ & $-0,596$ & $-0,801$ & $-0,093$ \\
\hline-4 & $-2,388^{*}$ & $-0,557$ & $-2,567^{*}$ & $-1,033$ & $-0,741$ & $-0,231$ \\
\hline-3 & $-1,527$ & $-0,724$ & $-1,060$ & $-1,214$ & $-0,821$ & $-0,384$ \\
\hline-2 & $-2,401^{*}$ & $-0,986$ & $-1,882$ & $-1,534$ & $-1,163$ & $-0,600$ \\
\hline-1 & $-2,745^{*}$ & $-1,285$ & $-2,445^{*}$ & $-1,951$ & $-1,154$ & $-0,814$ \\
\hline 0 & $-2,884^{* *}$ & $-1,599$ & $-1,809$ & $-2,259^{*}$ & $-1,667$ & $-1,123$ \\
\hline 1 & $-3,711^{* * *}$ & $-2,004$ & $-2,616^{*}$ & $-2,705^{* *}$ & $-1,972$ & $-1,490$ \\
\hline 2 & $-4,057^{* * *}$ & $-2,446^{*}$ & $-1,846$ & $-3,019^{* *}$ & $-2,761^{*}$ & $-2,003$ \\
\hline 3 & $-3,830^{* * *}$ & $-2,864^{* *}$ & $-1,174$ & $-3,219^{* * *}$ & $-2,946^{* *}$ & $-2,550^{* *}$ \\
\hline 4 & $-2,429^{*}$ & $-3,129^{* *}$ & 1,049 & $-3,040^{* *}$ & $-2,941^{* *}$ & $-3,096^{* *}$ \\
\hline
\end{tabular}

Where ${ }^{*},{ }^{* *}$ and ${ }^{* * *}$ denotes, respectively, $2,5 \%, 1 \%$ and $0,5 \%$ significance levels. 
Table A6. Moody's rating system

\begin{tabular}{|c|c|c|c|}
\hline Characterization of debt and issuer & & Rating & $\begin{array}{c}\text { Linear } \\
\text { transformation }\end{array}$ \\
\hline Highest quality & \multirow{10}{*}{ 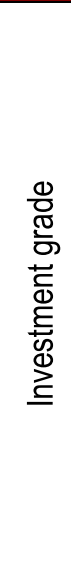 } & Aaa & 17 \\
\hline & & Aa1 & 16 \\
\hline High quality & & Aa2 & 15 \\
\hline & & Aa3 & 14 \\
\hline \multirow{4}{*}{ Strong payment capacity } & & $\mathrm{A} 1$ & 13 \\
\hline & & A2 & 12 \\
\hline & & A3 & 11 \\
\hline & & Baa1 & 10 \\
\hline \multirow[t]{2}{*}{ Adequate payment capacity } & & Baa2 & 9 \\
\hline & & Baa3 & 8 \\
\hline \multirow{3}{*}{$\begin{array}{l}\text { Likely to fulfill obligations, ongoing } \\
\text { uncertainty }\end{array}$} & \multirow{11}{*}{ 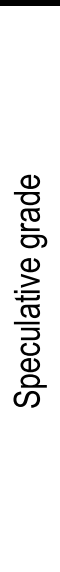 } & Ba1 & 7 \\
\hline & & $\mathrm{Ba} 2$ & 6 \\
\hline & & Ba3 & 5 \\
\hline \multirow{3}{*}{ High credit risk } & & B1 & 4 \\
\hline & & B2 & 3 \\
\hline & & B3 & 2 \\
\hline \multirow{3}{*}{ Very high credit risk } & & Caa1 & \\
\hline & & Caa2 & \\
\hline & & Caa3 & 1 \\
\hline Near default with possibility of recovery & & $\mathrm{Ca}$ & \\
\hline Default & & D & \\
\hline
\end{tabular}

Table A7. Causality test

\begin{tabular}{|l|l|l|}
\hline RBES do not cause RATBES & 0,51011 & 0,76879 \\
\hline RATBES do not cause RBES & 1,23358 & 0,29106 \\
\hline RBPI do not cause RATBPI & 0,86470 & 0,50420 \\
\hline RATBPI do not cause RBPI & 1,15335 & 0,33033 \\
\hline RBCP do not cause RATBCP & 0,29688 & 0,91474 \\
\hline RATBCP do not cause RBCP & 0,45017 & 0,81334 \\
\hline RPT do not cause RATPT & 8,38842 & 0,00000 \\
\hline RATPT do not cause RPT & 0,86252 & 0,50569 \\
\hline RBRISA do not cause RATBRISA & 1,77413 & 0,11525 \\
\hline RATBRISA do not cause RBRISA & 1,03545 & 0,39519 \\
\hline REDP do not cause RATEDP & 1,22728 & 0,29399 \\
\hline RATEDP do not cause REDP & 1,91286 & 0,08950 \\
\hline RREN do not cause RATREN & 0,62824 & 0,67827 \\
\hline RATREN do not cause RREN & 0,27058 & 0,92925 \\
\hline
\end{tabular}


Note: results obtained using 5 lags. 